\title{
UJI SIFAT FISIK DAN AKTIVITAS EKSTRAK DAUN PETAI CINA (Leucaena glauca, Benth) DALAM BERBAGAI TIPE BASIS SALEP SEBAGAI OBAT LUKA BAKAR
}

\author{
EVALUATION OF PHYSICAL PROPERTIES AND ACTIVITY \\ TEST OF EXTRACT OF (Leucaena glauca), Benth LEAVES IN \\ VARIATION TYPE OF BASE OINTMENT AS WOUND \\ HEALING
}

\author{
Olvia Becatami Widyantoro, Nining Sugihartini \\ Fakultas Farmasi Universitas Ahmad Dahlan \\ Email: nining.sugihartini@pharm.uad.ac.id
}

\begin{abstract}
ABSTRAK
Luka bakar merupakan kerusakan jaringan yang dapat disebabkan kontak dengan sumber panas. Daun petai cina mengandung senyawa aktif saponin, alkaloid, flavonoid dan tanin yang mempunyai aktivitas sebagai penyembuh luka bakar. Penelitian ini bertujuan mengetahui pengaruh tipe basis salep terhadap aktivitas penyembuhan luka bakar dan sifat fisiknya. Ekstrak daun petai cina diperoleh dengan metode maserasi menggunakan etanol 70\%. Ekstrak dibuat salep dengan basis salep hidrokarbon, absorbsi, larut air dan tercuci air. Salep dievaluasi sifat fisik meliputi uji organoleptis, homogenitas, $\mathrm{pH}$, daya lekat, daya sebar, proteksi dan daya penyembuh luka bakar menggunakan hewan uji marmut. Data yang diperoleh dianalisis menggunakan uji statistika dengan taraf kepercayaan $95 \%$.

Hasil uji menunjukkan bahwa urutan basis salep yang memberikan homogenitas yang bagus adalah hidrokarbon, absorbsi dan larut air. Urutan daya sebar terluas adalah hidrokarbon, larut air, absorbsi dan tercuci air. Dari hasil uji daya lekat urutan daya lekat dari yang terlama adalah hidrokarbon, absorbsi, larut air dan tercuci air, sedangkan urutan kecepatan penyembuhan luka bakar dari yang tercepat adalah hidrokarbon, absorbsi, larut air dan tercuci air. Diketahui pula bahwa tipe basis tidak mempengaruhi nilai $\mathrm{pH}$. Berdasarkan hasil tersebut dapat disimpulkan basis salep dari urutan terbaik adalah hidrokarbon, absorbsi, larut air dan tercuci air.
\end{abstract}

Kata kunci : ekstrak daun petai cina, tipe basis salep, obat luka bakar, sifat fisik salep

\begin{abstract}
Burn is a type of damage on skins tissue that is caused contact with high temperature. Petai Cina leaves content active compounds like saponin, alkaloid, flavonoid, and tannin that have activity as a wound healing. This research have purpose to know effect of ointment base on the activity of wound healing and the physical properties of the ointment. Petai Cina leaf extract is get with
\end{abstract}


macerations method by used ethanol 70\%. Extract is formulated in ointment with variation type of the base, hydrocarbon, absorption, soluble water, and washable water. Then ointment was evaluated the physical characteristic like organoleptic, homogeneity, $\mathrm{pH}$, adhesively, spread ability, protection and wound healing activity with guinea pig. The result show that the best of base of ointment which have best homogeneity are hydrocarbon, absorbs and soluble water; the best spread ability are hydrocarbon, soluble water, absorbs, and washable water. The best adhesively are hydrocarbon, absorbs, soluble water, and washable water, the best wound healing activity are hydrocarbon, absorbs, soluble water and washable water; and the type of base did not influence of $\mathrm{pH}$. Data is analyse statistic methode with 95\% level of confident. Variation of the type base of ointment gives different in physical properties ecxept $\mathrm{pH}$. Beside that the type base of ointment influenced the wound healing activity. Ointment base of best sequence is a hydrocarbon, absorption, soluble and washable.

Keywords : Petai Cina leaf extract, ointment base, wound healing, physical property of ointment

\section{PENDAHULUAN}

Luka bakar adalah

kehilangan jaringan yang disebabkan kontak dengan sumber panas seperti air, api, bahan kimia, listrik dan radiasi (Moenadjat, 2003). Luka bakar akan mengakibatkan tidak hanya kerusakan kulit, tetapi juga akan mempengaruhi seluruh sistem tubuh pasien. Pada pasien dengan luka bakar (mayor) tubuh tidak mampu lagi untuk berkompensasi sehingga timbul berbagai macam komplikasi yang memerlukan penanganan khusus (Effendi, 1999).

Salah satu bahan alam yang dapat digunakan dalam pengobatan luka bakar adalah daun petai cina. Saponin dalam daun petai cina mampu memacu pembentukan kolagen yaitu, protein struktur yang berperan dalam proses penyembuhan luka sekaligus mempunyai kemampuan sebagai pembersih sehingga efektif untuk penyembuhan luka terbuka (Fitriani et al., 2011). Proses terrsebut akan meningkatkan kecepatan epitelisasi jaringan luka (Igbinosa dan Aiyegoro, 2009). Selain itu kandungan taninnya yang merupakan polifenol dapat berfungsi mengikat dan mengendapkan protein. Penelitian lain tentang ekstrak daun petai cina menunjukkan hasil bahwa ekstrak daun petai cina memiliki manfaat sebagai antiinflamasi.

Berdasarkan uraian di atas, perlu dilakukan penelitian untuk memformulasikan ekstrak daun petai cina ini sebagai obat luka bakar 
dalam sediaan salep dengan berbagai tipe basis. Salep dipilih sebagai sediaan karena dapat langsung diaplikasikan pada tempat luka sehingga akan memberikan efek yang diinginkan. Selain itu sediaan salep juga mudah digunakan. Dalam formulasi salep perlu diketahui tipe basis yang cocok agar pelepasan zat aktif dapat maksimal sehingga diperoleh efek terapetik yang maksimal. Untuk itu, perlu dilakukan penelitian untuk mengetahui basis yang cocok dalam pembuatan salep ekstrak daun petai cina agar mendapatkan efek optimum sebagai penyembuh luka bakar. Basis yang digunakan dalam penelitian ini adalah basis hidrokarbon, basis absorpsi, basis larut air dan basis tercuci air.

\section{METODE PENELITIAN}

Daun petai cina (Leucaena glauca, Benth.) yang diperoleh dari Bantul. Basis salep dengan derajat farmasetis yaitu : PEG 400, PEG 4000, vaselin putih, lemak bulu domba, stearil alkohol, malam putih, natrium lauril sulfat, propilen glikol dan aquadest, etanol $70 \%$ sebagai pelarut dan etil klorida sebagai anastesi.
Alat yang digunakan dalam penelitian ini meliputi timbangan, kandang, alat-alat gelas, alat penginduksi panas modifikasi, alat pencukur bulu marmut, lempeng kaca berskala, alat uji daya sebar, alat uji daya lekat, alat uji daya proteksi, alat uji homogenitas, kertas $\mathrm{pH}$, pot salep, perban, kapas, plester, gunting, dan penggaris.

Hewan percobaan yang digunakan marmut (Cavia porcellus) yang dipelihara dalam kandang individual.

Jalannya Penelitian

1. Pembuatan Ekstrak Daun Petai Cina

Ekstrak daun petai cina diperoleh dengan metode maserasi menggunakan etanol 70\%. Serbuk dibagi menjadi dua bagian yang sama banyak dan masing-masing ditambah pelarut ertanol $70 \%$ sebanyak $1500 \mathrm{ml}$ sampai semua bahan terendam. Maserat yang diperoleh melalui penyaringan disatukan, diuapkan diatas penangas air dengan menggunakan cawan porselin hingga diperoleh ekstrak kental daun petai cina yang kemudian ditimbang untuk mengetahui beratnya. 
2. Pembuatan Sediaan Salep daun petai cina kemudian diaduk dengan Variasi Tipe Basis

Formula sediaan salep dalam basis hidrokarbon, basis absorbsi, basis larut air, dan basis tercuci air disajikan dalam tabel I.

a. Pembuatan Salep Basis

Hidrokarbon

Vaselin putih dan minyak mineral dilelehkan di atas waterbath, diaduk hingga homogen. Basis salep dicampur dengan ekstrak daun petai cina dalam mortir kemudian diaduk sampai homogen dan didiamkan sampai dingin. Salep kemudian dimasukkan dalam pot salep.

b. Pembuatan Salep Basis Absorpsi

Malam putih dilelehkan di atas waterbath, lalu ditambahkan vaselin putih, stearil alkohol, dan lemak bulu domba. Campuran dipanaskan sampai mencair, diaduk hingga homogen dan kemudian diangkat dan dipindahkan dalam mortir. Basis kemudian dicampur dengan ekstrak hingga homogen. Salep dimasukkan dalam pot salep.

c. Pembuatan Salep Basis Larut Air PEG 4000 dilelehkan bersamaan kemudian diaduk hingga homogen. dengan PEG 400, kemudian diaduk hingga homogen. Basis salep dicampur dengan ekstrak daun petai cina dalam mortir Salep kemudian diletakkan dalam pot salep.

d. Pembuatan salep Basis Tercuci Air

Stearil alkohol dengan vaselin putih dilelehkan di atas waterbath hingga suhu $75^{\circ} \mathrm{C}$. Dan Na lauril sulfat, propilen glikol dan aquadest dipanaskan hingga suhu $75^{\circ} \mathrm{C}$. Kedua masa lelehan lalu dicampurkan dan diaduk sampai dingin. Masa basis kemudian ditambah ekstrak daun petai cina dan diaduk hingga homogen. Salep kemudian dimasukkan dalam pot salep. 
Tabel I. Formula Salep Ekstrak Daun Petai Cina dalam Berbagai Tipe Basis.

\begin{tabular}{lllll}
\hline \multirow{2}{*}{ Bahan } & \multicolumn{4}{l}{ Formula Salep Ekstrak Daun Petai Cina } \\
\cline { 2 - 5 } & F I & F II & F III & F IV \\
\hline Ekstrak daun petai cina & $3,75 \mathrm{~g}$ & $3,75 \mathrm{~g}$ & $3,75 \mathrm{~g}$ & $3,75 \mathrm{~g}$ \\
Vaselin putih & $19,125 \mathrm{~g}$ & $18,232 \mathrm{~g}$ & $5,313 \mathrm{~g}$ & - \\
Parafin cair & $2,125 \mathrm{~g}$ & - & - & - \\
Lemak bulu domba & - & $0,638 \mathrm{~g}$ & - & - \\
Stearil alkohol & - & $0,638 \mathrm{~g}$ & $5,313 \mathrm{~g}$ & - \\
Malam putih & - & $1,7 \mathrm{~g}$ & - & - \\
Natrium lauril sulfat & - & - & $0,212 \mathrm{~g}$ & - \\
Propilen glikol & - & - & $2,55 \mathrm{~g}$ & - \\
PEG 4000 & - & - & - & $8,5 \mathrm{~g}$ \\
PEG 400 & - & - & - & $12,75 \mathrm{~g}$ \\
Aquadest & - & - & $7,862 \mathrm{~g}$ & - \\
Salep ad & $25 \mathrm{~g}$ & $25 \mathrm{~g}$ & $25 \mathrm{~g}$ & $25 \mathrm{~g}$ \\
\hline
\end{tabular}

Keterangan:

F I : Formula salep dengan basis Hidrokarbon

F II : Formula salep dengan basis Absorbsi

F III : Formula salep dengan basis Larut Air

F IV : Formula salep dengan basis tercuci Air

3. Uji Sifat Fisik Salep

a. Uji Daya Lekat

Salep di letakkan di atas objek gelas, dan objek gelas yang lain diletakkan di atasnya dan ditekan dengan beban seberat $1 \mathrm{~kg}$ selama 5 menit. Objek gelas dipasang pada alat uji. Beban seberat $80 \mathrm{~g}$ dilepaskan dan dicatat waktunya sehingga kedua objek gelas tersebut terlepas (Oetary, 1987).

b. Uji Daya Sebar

Menimbang $500 \mathrm{mg}$ salep daun petai cina dan diletakkan di tengah kaca bulat berskala. Sebelumnya ditimbang dahulu kaca yang lain dan diletakkan kaca tersebut diatas salep dan dibiarkan selama 1 menit. Diameter salep yang menyebar diukur dengan mengambil panjang rata-rata diameter dari beberapa sisi. Diameter salep yang menyebar dicatat sampai beban seberat 200 gram (Oetary, 1987).

\section{c. Uji pH}

Uji $\mathrm{pH}$ dilakukan dengan menggunakan kertas $\mathrm{pH}$.

\section{d. Uji Homogenitas}

Sediaan salep daun petai cina dioleskan pada obyek glas. Sediaan salep kemudian digosok dan diraba untuk mengetahui homogenitasnya. 


\section{e. Uji Daya Proteksi}

Salep dioleskan pada kertas saring yang sebelumnya sudah ditetesi fenolftalein. Kertas tersebut ditempelkan pada kertas saring lainnya yang kemudian ditetesi larutan $\mathrm{KOH} \quad 0,1 \quad \mathrm{~N}$. Pengamatan dilakukan pada waktu 15 detik, 30 detik, 45 detik, 60 detik, 3 menit, dan 5 menit setelah $\mathrm{KOH}$ diteteskan dengan mengamati munculnya warna merah.

\section{Uji Penyembuhan Luka Bakar}

$$
\text { Pada pengujian daya }
$$

penyembuhan luka bakar diperlukan sebanyak 4 kelompok marmut. Pengelompokan dan perlakuannya adalah tiap marmut dibuat luka bakar pada bagian punggung sebanyak 4 bagian. Setiap marmut mendapat perlakuan yang sama yaitu diolesi salep basis hidrokarbon, basis absorbsi, basis larut air dan basis tercuci air. Kemampuan penyembuhan luka bakar diukur berdasarkan diameter luka sampai hari ke-30.

\section{Analisis Data}

Data sifat fisik salep dan daya penyembuhan luka bakar dianalisis menggunakan SPSS 16 for windows dengan uji Kolmogorov-Smirnov untuk melihat homogenitasnya dan uji Levene untuk melihat profil distribusinya. Selanjutnya data dianalisis menggunakan metode parametrik atau non-parametrik pada taraf kepercayaan $95 \%$.

\section{HASIL DAN PEMBAHASAN}

A. Identifikasi Senyawa Ekstrak Daun petai Cina

Identifikasi kandungan senyawa aktif dalam ekstrak daun petai cina dilakukan dengan uji tabung dan uji KLT. Hasil uji tabung pada ekstrak daun petai cina menunjukkan bahwa ekstrak mengandung senyawa saponin, alkaloid, tanin dan flavonoid seperti disajikan pada gambar 1 dan hasil uji KLT disajikan pada tabel II dan gambar 2. 


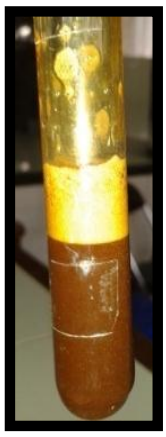

a.

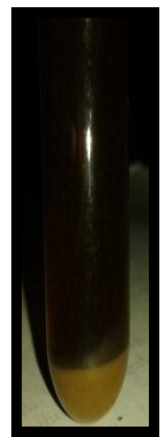

b.

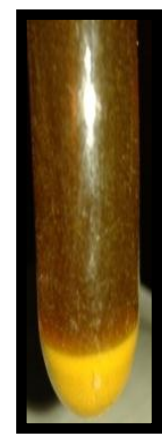

c.

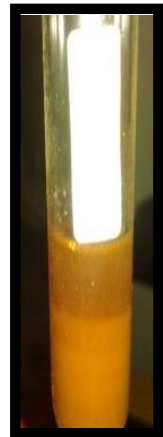

d.

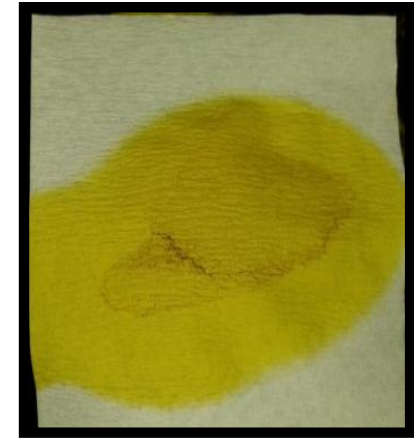

e.

Gambar 1.Hasil Uji Tabung Ekstrak Daun Petai Cina

a. Uji saponin, b. Uji Tanin, c. Uji Alkaloid, d. Uji Alkaloid, e. Uji Flavonoid
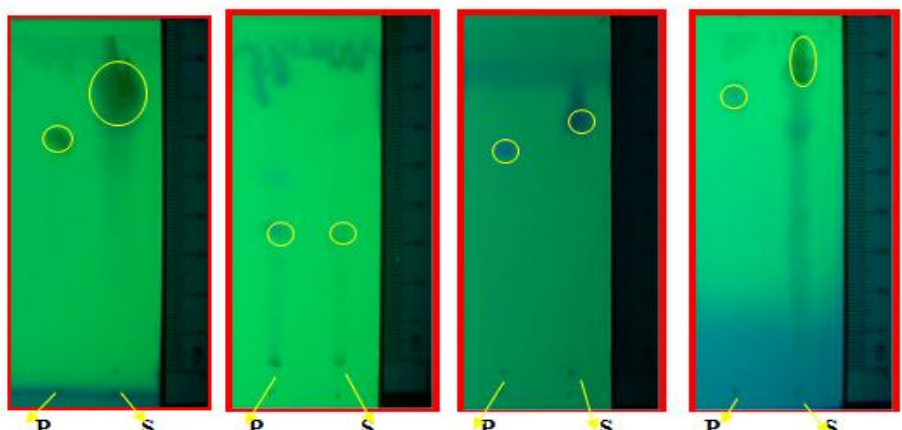

Gambar 2. Hasil uji KLT Senyawa Aktif Dalam Ekstrak Daun Petai Cina

Keterangan:

a. Flavonoid

$\mathrm{P}=$ Rutin

$$
\begin{aligned}
& \text { b. Alkaloid } \\
& P=\text { Quinin } \\
& S=\text { Ekstrak }
\end{aligned}
$$

c. Saponin
$\mathrm{P}=$ Saponin
$\mathrm{S}=$ Ektrak

d. Tannin

$\mathrm{P}=$ Tannin

$\mathrm{S}=$ Ekstrak

$\mathrm{S}=$ Ekstrak

Tabel II. Nilai Rf Kandungan Senyawa Aktif Ektrak Daun Petai Cina

\begin{tabular}{cc}
\hline Senyawa & Nilai Rf \\
\hline Saponin & 0,78 \\
Alkaloid & 0,65 \\
Falvonoid & 0,7 \\
Tannin & 0,8 \\
\hline
\end{tabular}

B. Uji Sifat Fisik Salep Ekstrak Daun Petai Cina

\section{Uji Organoleptis}

Hasil uji organoleptis salep ekstrak daun petai cina dengan variasi basis salep disajikan pada tabel III. 
Tabel III. Hasil uji organoleptis salep dengan variasi tipe basis

\begin{tabular}{lcccc}
\hline \multirow{2}{*}{ Organoleptis } & \multicolumn{4}{c}{ Basis Salep } \\
\cline { 2 - 5 } & Hidrokarbon & Absorbsi & Larut Air & Tercuci Air \\
\hline Warna & Coklat & Coklat & Coklat & Kuning kecoklatan \\
Bau & Khas & Khas & Khas & Khas \\
\hline
\end{tabular}

Data pada tabel menunjukkan bahwa perbedaan basis salep pada sediaan akan mempengaruhi warna dan konsistensi salep ekstrak daun petai cina tersebut. Salep ekstrak daun petai cina dengan basis hidrokarbon memiliki massa yang lebih lembek karena mengandung minyak, sehingga akan menurunkan viskositasnya dan dihasilkan konsistensi yang lebih lembek. Sedangkan salep dengan basis absorbsi, larut air dan tercuci air memiliki massa yang tidak terlalu lembek karena lebih sedikit komposisi bagian lemaknya atau tidak terdapat minyak dalam sediaannya, sehingga dihasilkan konsistensi yang lebih keras. Warna salep dengan basis hidrokarbon, absorpsi dan larut air adalah coklat sedangkan pada basis tercuci air memiliki warna kuning kecoklatan.

\section{Uji Homogenitas}

Hasil uji menunjukkan bahwa salep dengan basis hidrokarbon, absorbsi dan larut air sudah tercampur homogen. Hal itu berdasarkan tidak adanya gumpalan maupun butiran kasar pada sediaan salep ekstrak daun petai cina. Dengan demikian diharapkan sediaan salep tersebut dapat terdistribusi rata pada kulit dan tidak menimbulkan iritasi.

\section{3. $U j i p H$}

Hasil uji pH menunjukkan bahwa $\mathrm{pH}$ salep ekstrak daun petai cina pada berbagai tipe basis memiliki $\mathrm{pH}$ yang sama yaitu 5. Hal ini menunjukkan bahwa tipe basis salep tidak mempengaruhi $\mathrm{pH}$ sediaan. Sediaan memiliki $\mathrm{pH}$ yang masih aman karena masih masuk dalam pH kulit yaitu 4,5-6,5 (Tranggono, 2007). 


\section{Uji Daya Lekat}

Hasil uji menunjukkan bahwa basis hidrokarbon memiliki daya lekat lebih lama daripada basis absorbsi,larut air dan tercuci air. Hal ini dikarenakan basis hidrokarbon mengandung minyak mineral atau parafin cair yang bersifat lemak sehingga melekat lama pada kulit. Semakin tinggi kandungan bahan bersifat lemak dalam formula basis maka daya lekat menjadi semakin meningkat. Dari uji LSD dapat diketahui bahwa basis hidrokarbon mempunyai daya lekat yang berbeda dengan basis absorbsi, basis larut air dan basis tercuci air $(\mathrm{p}<0,05)$. Urutan tipe basis dari yang paling lama yaitu basis hidrokarbon, basis absorbsi, basis larut air dan yang paling singkat adalah basis tercuci air. Profil uji daya lekat dapat dilihat pada gambar 3.

\section{Uji Daya Sebar}

Hasil uji daya sebar menunjukkan bahwa terdapat perbedaan daya sebar yang signifikan antara basis hidrokarbon, basis absorbsi, basis larut air dan tercuci air $(\mathrm{p}<0,05)$. Dari data tersebut daya sebar yang paling luas yaitu basis hidrokarbon sedangkan yang paling sempit yaitu basis tercuci air. Hal ini dikarenakan masa basis salep hidrokarbon memiliki konsistensi yang lebih lembek dibandingkan dengan bais yang lain. Urutan daya lekat dari yang memiliki daya sebar paling luas adalah basis hidrokarbon, basis larut air, basis absorbsi dan daya sebar yang sempit adalah basis tercuci air seperti disajikan pada gambar 4.

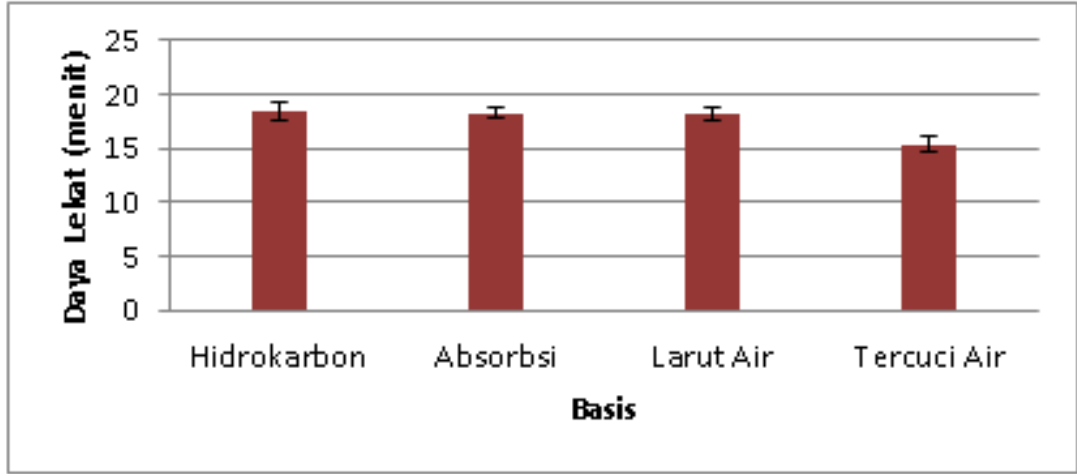

Gambar 3. Diagram Uji Daya Lekat Salep dengan Variasi Tipe Basis 


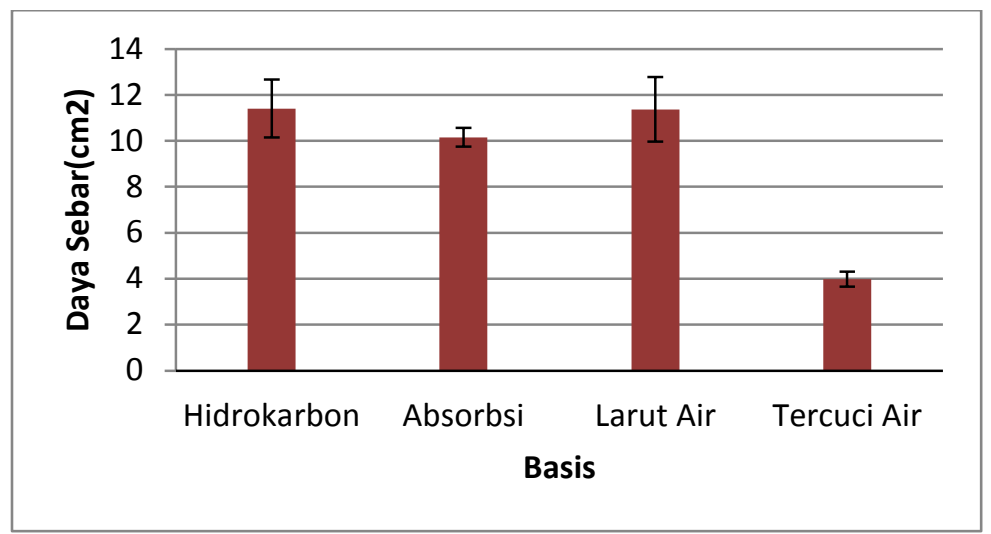

Gambar 4. Diagram Uji Daya Sebar Salep dengan Variasi Tipe Basis

\section{Uji Daya Proteksi}

Hasil uji daya proteksi menunjukkan bahwa salep dengan basis hidrokarbon, basis absorbsi, dan basis larut air memiliki daya proteksi lebih lama karena pada waktu 5 menit belum menimbulkan noda merah. Sedangkan pada basis tercuci air hanya dapat memberikan daya proteksi sampai menit ke-3. Hal ini disebabkan pada basis hidrokarbon, basis absorbsi dan basis larut air mengandung komponen lemak sehingga mampu memberikan proteksi lebih lama.

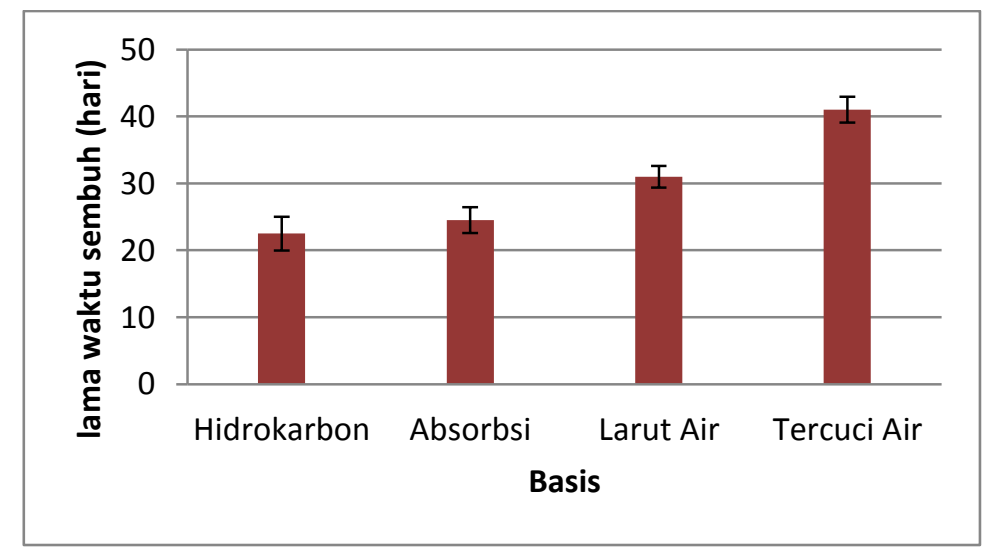

Gambar 5. Diagram Lama Waktu Sembuh pada Tiap Tipe Basis 
7. Lama Waktu Penyembuhan Luka Bakar

Hasil uji lama penyembuhan luka bakar disajikan pada Gambar 5. Waktu yang diperlukan untuk menyembuhkan luka bakar dengan indikator kesembuhan diameter $0 \mathrm{~cm}$ (persentase $100 \%$ sembuh) berturutturut dari yang paling cepat adalah basis hidrokarbon $(23,5 \pm 2,52$ hari), basis absorbsi (24,5 $\pm 1,91$ hari), basis larut air (31 $\pm 1,63$ hari), dan basis tercuci air $(42,5 \pm 1,91$ hari). Basis hidrokarbon memiliki kecepatan penyembuhan luka yang tercepat, karena memiliki daya lekat paling lama sehingga obat dalam salep lebih lama menempel dan kemudian terserap ke dalam kulit lebih banyak. Basis absorpsi merupakan salep berlemak yang memiliki sifat menyerupai basis hidrokarbon, akan tetapi tidak memiliki derajat penutupan pada kulit sebaik basis hidrokarbon sehingga absorpsi obat tidak begitu cepat. Basis larut air memiliki sifat suka air, tidak berlemak dan larut dalam air sehingga kadar yang dapat terserap tidak sebanyak basis hidrokarbon dan basis absorbsi. Basis tercuci air mengandung fase air dan fase minyak sehingga proses hidrasi yang ditimbulkan tidak sebaik basis larut air yang tidak mengandung bahan berlemak dan meskipun mengandung bahan berlemak, basis ini tidak mempunyai derajat penutupan seperti yang diberikan oleh basis hidrokarbon dan absorpsi sehingga absorpsi obat tidak begitu cepat.

Dengan demikian dapat dinyatakan bahwa waktu kontak sediaan dengan permukaan kulit juga berpengaruh pada absorpsi obat melalui kulit. Semakin besar waktu kontak obat pada kulit maka konsentrasi obat yang diabsorpsi oleh kulit semakin meningkat. Basis hidrokarbon dan absorpsi memiliki waktu kontak yang lebih lama dibandingkan dengan lainnya karena sifat dari basis hidrokarbon dan absorpsi sebagai penutup yang baik pada kulit, sedangkan basis tercuci air dan larut air merupakan basis yang mudah dicuci maupun larut dalam air sehingga waktu kontak dengan permukaan kulit relatif lebih cepat. Selain itu, daya sebar mempengaruhi proses penyembuhan luka karena dengan semakin luas penyebaran, maka semakin luas pula 
luka tertutup oleh obat sehingga luka cepat sembuh.

Berdasarkan hasil uji normalitas dengan uji Kolmogorov-Smirnov diperoleh nilai $\mathrm{p}<0,05$ sehingga data terdistribusi normal kemudian dilakukan uji homogenitas dengan uji levene nilai $\mathrm{p}>0,05$ sehingga data homogen. Selanjutnya dilakukan uji analisis LSD pada taraf kepercayaan 95\%. Dari hasil uji statistic dapat disimpulkan bahwa tidak ada perbedaan yang bermakna antara salep basis hidrokarbon dengan basis absorbsi, hal ini ditunjukkan dengan nilai > 0,05. Hal ini disebabkan komposisi minyak pada basis hidrokarbon hampir sama dengan basis absorbsi sehingga pelepasan bahan aktifnya hampir sama dengan basis lainnya.

Aktivitas ekstrak daun petai cina disebabkan kandungan tannin dan saponin yang dapat merangsang pembentukan sel epitel baru dan mendukung proses epitelisasi sehingga dapat menyebabkan pengecilan ukuran luka bakar yang berkorelasi dengan proses reepitelisasi, semakin cepat reepitelisasi maka semakin mengecil ukuran luka sehingga mempersingkat waktu penyembuhan luka (Haris, 2011). Saponin dan tanin dalam ekstrak diketahui dapat merangsang terjadinya angiogenesis (Majewska dan Gendaszewska, 2011 dan Li et $a l ., 2011)$ yang nerupakan salah satu bagian dalam proses penyembuhan luka (Morison, 2003). Selain itu, saponin dapat memacu pertumbuhan kolagen dalam proses penyembuhan luka (Igbinosa dan Aiyegoro, 2009). Selain itu kandungan flavonoid bekerja dalam proses membunuh atau menghambat pertumbuhan mikroorganisme pada jaringan yang hidup seperti pada permukaan kulit dan membran mukosa dan juga dapat mengurangi inflamasi dengan cara menghambat siklooksigenase dan lipooksigenase (Harris, 2011).

\section{KESIMPULAN}

1. Perbedaan tipe basis salep mempengaruhi warna, daya lekat, daya proteksi dan daya sebar salep namun tidak mempengaruhi pH pada sediaan

a. Variasi basis salep memberikan pengaruh terhadap lama penyembuhan luka bakar. Basis hidrokarbon memberikan aktivitas 
tertinggi atau efek optimal pada

proses penyembuhan luka bakar.

\section{Ucapan Terima Kasih}

Mengucapkan terima kasih kepada segenap pihak yang telah membantu dalam penyelesaian penelitian ini.

\section{DAFTAR PUSTAKA}

Effendi, C., 1999, Perawatan Pasien Luka Bakar, Puspa Swara, Jakarta : 97-102.

Fitri, Ana., Ferariani., Tyas , Atiah Hestining., Irmmal., 2011, Petai Cina sebagai Obat luka, diakses dari http://fmipa.uny.ac.id/berita/p etai-cina-sebagai-obat-

luka.html pada tanggal 9 Mei 2015.

Haris, M., 2011, Penentuan Kadar Flavanoid Total dan Aktivitas Antioksidan dari Getah Jarak Pagar dengan Spektrofotometer UVVisibel, Skripsi, Fakultas Farmasi. Universitas Andalas, Padang.

Igbinosa E.O., and Aiyegoro, O.A., 2009, Antimicrobial Activity and Phytochemical Screening of Steam Bark Extracts from Jatropha curcas (Linn).
African Journal of Pharmacy and Pharmacology, 3(2): 058062.

Li, K., Dao, Y., Zhang, H., Wang, S., Zhang, Z., Yu, B., Huang, S., and Yang, H., 2011, Tannin Extracts from Immature Fruits of Terminalia chebula Fructus Retz Promote Cutaneous Wound healing in rats, $B M C$ Complementary and Alternative Medicine.

Majewska, I. dan Gendaszewska, E, Proangiogenic Activity of Plant Extracts in Acceleraty Wound healing- A New Face of Old Phytomedicine, ACTA ABP Biochimica Polonica, 58 : 449460.

Moenadjat., 2003, Luka Bakar, Edisi IV, Fakultas Kedokteran Universitas Indonesia, Jakarta : $1-5,112-113$.

Morison, J.Moya., 2003, A Colour Guide The Nursing Management of Wounds, EGC, Jakarta : 10-20.

Oetary, S., 1987, Pengaruh Surfaktan Non Ionik yang Dicampur Dalam Basis Salep Hidrofil (USP) Terhadap Pelepasan Asam Salisilat Secara In Vitro, Thesis, Fakultas Farmasi UGM, Yogyakarta.

Tranggono., 2007, Buku Pegangan Ilmu Pengantar Kosmetik, Jakarta,Gramed 